\title{
KINOSAKI NITE (1) DE NAOYA SHIGA
}

\section{Luiza Nana Yoshida}

Ainda não me foi possivel fazer um estudo aprofundado a respeito da obra e da vida de Naoya Shiga (2), embora fosse grande o meu interesse por ele. Este artigo não tem, portanto, a pretensão de ser um estudo crítico a respeito das obras deste renomado escritor, apenas me limito a relatar as minhas impressões através da sua obra Kinosaki nite.

Kinosaki nite não possui um enredo propriamente dito, pois consiste em uma reflexão feita pelo "eu" (3) a respeito da vida e da morte, depois de ter sofrido um acidente quase fatal, e de ter sentido a morte bem de perto.

Para a convalescença, o "eu" vai descansar nas termas de Kinosaki (4) onde num curto periodo de tempo depara com a morte de uma abelha, de um rato e de uma lagartixa d'água, em circunstâncias diversas.

A primeira morte se refere à da abelha que encontra já morta, no telhado que se vê da sacada do seu quarto no segundo andar da hospedaria.

O personagem nota que há uma colméia entre as ripas que ficam na divisória do telhado do hall de entrada e da parede da casa. Quan. do o tempo está bom, há um movimento constante de entrar e sair das abelhas entre as ripas e, numa certa manhã, o "eu" descobre uma abelha morta no telhado do hall de entrada.

Segundo muitos críticos japoneses, a qualidade maior de Shiga está na sua linguagem extremamente bem cuidada, clara, correta, que o torna capaz de transmitir aos leitores, tudo aquilo que vê, de uma maneira fiel, ou seja, assim como ele realmente a vê, utilizando-se de um vocabulário simples, mas expressivo. 
Sua linguagem torna-se quase que visual, motivada pela habilidade com que Shiga utiliza o vocabulário adequado nos lugares devidos, e pela sabedoria com que escolhe a palavra, fatores esses que possibilitam formar a imagem fiel do quadro que quer transmitir.

Muitos críticos já chamaram a atençáo para essa qualidade de Shiga, tanto que trechos da sua obra Kinosaki nite são citados como linguagem modelo da língua japonesa.

Junichiro Tanizaki, por exemplo, em seu Bunshö Dokuhon (5) (Modelos de Linguagem), destaca, à certa altura, o trecho em que é narrado o episódio da abelha para o desenvolvimento do seu estudo. Ele chama a atençăo, por exemplo, para a observação minuciosa que o autor faz, escrevendo exatamente conforme seus olhos viram, sobre a abelha que sai da colméia e alça vôo.

"As abelhas, deslizando-se por entre as ripas, pousam, de in icio, no telhado do hall de entrada. Al, depois de examinarem cuidadosamente as asas $e$ as antenas com as patas dianteiras e traseiras, algumas passeiam um pouco, mas logo estendem, firmes, as asas alongadas para os lados e alçam vôo soltando um zumbido. Ao alçar vôo, tornam-se rápidas repentinamente e somem.

Um certo dia, o "eu" descobre uma abelha morta no dito telhado do hall de entrada. Ela está com as patas encolhidas sobre o ventre e as antenas caídas desleixadamente. Essa abelha, tão quieta em seu lugar, contrasta com as outras que trabalham apressadamente, fazen. do com que pareçam extremamente cheias de vida. Vê-la tão quieta e sozinha no telhado, depois que as outras se recolhiam, dava ao "eu" uma sensação de melancolia, embora esse sentimento estivesse envolto num clima de muita tranqüilidade. A morte que ele vira de tão perto se the afigurava então como algo muito íntimo e sereno.

"Mesmo agora, as abelhas da colméia estão trabalhando energica. mente, mas a abelha morta deve ter sido arrastada para o chão através da calha. Deve estar imóvel em algum lugar, com as patas encolhidas, as antenas grudadas no rosto e talvez coberta de lama. O cadáver deve ficar hirto aí, até que ocorra no exterior, uma outra mudança que o movimente. Ou será arrastado pelas formigas? Não obstante, isso era extremamente sereno. 0 completo cessar dos movimentos daquela que trabalhava sem tréguas, proporcionava tranqüilidade. Eu senti uma familiaridade com 
relação a essa tranqüilidade"'

Decorrido pouco tempo desde a morte da abelha, o "eu" encontra, certa manhã, uma multidão a olhar em direçao a um certo ponto do rio. Nota um rato com um espeto para peixe de aproximadamente $21 \mathrm{~cm}$ transpassado em seu pescoço. As extremidades do espeto surgiam a uns $9 \mathrm{~cm}$ acima da cabeça e $9 \mathrm{~cm}$ abaixo do pescoço.

O rato nadava debalde de um lado para o outro tentando sair do rio, mas as extremidades do espeto atrapalhavam-no, e ele não conseguia subir pela margem coberta de pedra (6). Empenhava-se em se salvar, como se houvesse alguma possibilidade, fugindo para algum lugar.

Para o "eu", aquela imagem do rato debatendo-se para se salvar a qualquer custo, embora já praticamente clara a sua morte, deixou marcas em sua memória.

Esse quadro fá-lo conscientizar-se da realidade cruel que existe anteriormente à morte.

"Eu fiquei com um sentimento de tristeza e repulsa. Pensei: aquela é que é a realidade. E amedrontador o fato de existir um sofrimento como aquele, antes da tranqüilidade que estou desejando. Mesmo que eu sinta intimidade com relaçáo à serenidade do momento após a morte, pensei: aquela agitação pela qual se passa até se chegar à morte é amedrontador. Os animais, que não conhecem o suicídio são obrigados a continuar com aquele esforço até alcançarem finalmente a morte."

A posição do "eu" diante da morte vai agora caminhar para uma reflexão mais profunda, ligada ao instinto de sobrevivência que tanto o animal, como o homem possuem dentro de si.

0 "eu" que de in ício tem uma postura digamos estática, com relação à morte,

"Por um triz, a essas horas, estaria deitado de costas debaixo da terra de Aoyama (7). Com a cara pálida, gelada e dura, com os ferimentos do rosto e das costas intactos. Do lado estáo os restos mortais do meu avô e da minha mãe. E estes também, sem terem nenhuma relação entre si - brotam-me pensamentos assim. Isso é melancólico. Mas era um pensamento que não me amedrontava tanto assim." 
percebe que existe uma luta ferrenha antes de se chegar à morte, e se conscientiza de que ele mesmo havia travado essa luta na época do acidente, quando sem perceber, o seu instinto de sobrevivência havia falado mais alto que a sua razão.

"Eu tentei fazer tudo que me fosse possível. Eu próprio escolhi - hospital. Indiquei como chegar a ele. Pedi, por exemplo, para que telefonassem antes, pensando que seria problemático não se poder fazer os preparativos para a operação logo que chegasse, caso o médico estivesse ausente. $O$ fato de a cabeça ter funcionado eficientemente a respeito das coisas mais importantes, mesmo num estado de semi-consciência, a mim mesmo pareceu, mais tarde, estranho."

O que the causou estranheza também foi o fato de ele não ter praticamente se apavorado com a gravidade do seu ferimento, que poderia se tornar fatal. Embora não 0 apavorasse, não pôde negar que cresceu dentro dele uma alegria inexplicável ao ouvir o médico dizer que não era um ferimento fatal. Não saberia dizer qual seria a sua reação se tivesse ouvido que iria morrer, mas sente que, mesmo assim, procuraria uma maneira de se salvar e faria qualquer esforço para continuar a viver. $E$ isso seria algo semelhante ao instinto de sobrevivência do rato.

Percebemos que há dentro do "eu" duas forças contrastantes: o sentimento de proximidade com a morte que não o amedronta $e$, ao mesmo tempo, a vontade de viver que o impele a se agarrar em qualquer coisa que the permita continuar vivendo. Qual seria, então, a sua reação com relação a essas duas forças?

O sentimento do "eu" parece caminhar para uma aceitação das duas forças como algo inevitável, e isso parece evidenciar-se mais na cena da lagartixa d'água.

Certo entardecer, durante o seu passeio ao longo de um rio, o "eu" vê uma lagartixa d'água numa pedra, na margem oposta. Fica contemplando o pequeno animal por algum tempo e, a certa altura, atira uma pedra com a intenção de assustá-lo. Por um desses caprichos da natureza, ele que nunca conseguira antes acertar num único alvo, mesmo mirando, acaba pegando em cheio e matando a pobre lagartixa. Ele próprio não acreditava no que fizera. Não conseguia entender por que isso acontecera. Não tinha como explicar essa morte senão atribuindo-a ao acaso. Foi uma morte súbita e inesperada. 
"Para a lagartixa foi uma morte completamente inesperada. Eu fiquei aí agachado por algum tempo. Senti como se restássemos só eu e a lagartixa, e senti isso colocando-me no lugar dela. Ao mesmo tempo que tinha pena, senti também a solidão do ser vivo. Foi por acaso que não morri. A lagartixa morreu casualmente."

A vida e a morte são de certo modo inexplicáveis. Não há como criar uma vida a partir de matérias artificiais, nem evitar uma morte física eternamente. A vida e a morte sáo também inseparáveis, pois uma não existiria sem a outra. Por força do acaso, ora estamos vivos, ora morremos. Não há como lutar contra isso.

Parece ser mais ou menos essa a conclusão a que o "eu" chega. Ele parece entregar a vida e a morte às mãos do acaso. $O$ homem se torna impotente diante disso e não há muito a fazer senão esperar que num belo dia a morte chegue.

"O que teria acontecido com a abelha? Deve estar já debaixo da terra, arrastada pela chuva que caiu após a sua morte. 0 que teria acontecido com aquele rato? Arrastado para o mar, a essas alturas, esse corpo inchado de água deve ter sido trazido para a praia junto com os detritos. $E$ eu, que não morri, estou agora aqui. Assim pensei. Senti também que deveria estar agradecido com relação a isso. Mas a verdade é que não nasceu dentro de mim o sentimento de alegria. O viver e o morrer, esses dois fatos, não são opostos. Pareceu-me não haver tanta diferença assim "

Apesar do relato de três episódios aparentemente independentes, notamos que existe uma estruturação dentro da obra, onde o fio mestre de ligação é o sentimento do "eu" que varia diante de cada uma das mortes:

a) abelha: temos aqui a morte já consumada, que surge como algo tranqüilo e pela qual o "eu" nutre até uma certa intimidade. E - contraste entre a vida agitada, representada pelas abelhas da colméia, e a morte, na figura da abelha morta. A vida é como sinônimo de agitação e a morte, de tranqüilidade.

b) rato: é o retrato da transição, a fase intermediária entre a vida e 
a morte. Diante de toda a luta pela qual se tem que passar até atingir a morte, 0 "eu" sente medo, e carrega dentro dele um sentimento contraditório: a intimidade com a morte e o apego à vida. Isso o leva a pensar que, tanto a vida como a morte säo verdadeiras, e que a escolha entre as duas não está ao alcance do homem.

c) lagartixa: a vida que sucumbe diante dos olhos do "eu", por mera casualidade. Ele próprio sendo o causador direto da morte, fica perplexo diante da fugacidade da vida. Percebe que não possui poderes para controlar nem a vida e nem a morte. É o sentimento de incerteza diante de uma realidade que não consegue mudar.

Se atentarmos para as ligações eu-abelha, eu-rato e eu-lagartixa, temos:

a) eu-abelha: após a morte e o desaparecimento do corpo da abelha, o "eu" imagina o que teria acontecido com ela.

"Deve estar imóvel em algum lugar, com as patas encolhidas, as antenas grudadas no rosto e talvez coberta de lama."

ou

“Deve estar já debaixo da terra arrastada pela chuva que caiu após sua morte."

b) eu-rato: vendo o rato que diante da morte iminente luta de todas as formas para sobreviver, 0 "eu" recorda-se do seu acidente e reflete sobre a sua reação diante de uma situação semelhante à do rato.

"Se tivesse ouvido que era fatal, como eu teria reagido? Esse "eu" é um pouco difícil de imaginar. Eu teria ficado abatido. Mas, sinto que não seria acometido de um pavor com relação à morte, assim como penso normalmente. E sinto que mesmo me tendo sido comunicado isso, ainda assim, eu pensaria em me salvar e teria feito qualquer esforço para isso."

c) eu-lagartixa: aqui, o que existe é o "eu" perante a realidade da qual não se pode fugir Em questão de segundos, a lagartixa tão cheia de vida cai morta diante dos seus olhos. A perceber pelo trecho:

"É uma lagartixa d'água. Ela ainda está molhada e tem uma 
bonita cor. (. .) peguei a pedra e a atirei. (. .) Então, a lagartixa acabou tombando para a frente sem forças, quando os dedos das duas patas dianteiras se encolheram, depois de, com os cotovelos afastados, resistir à inclinação (da pedra). $O$ rabo aderiu completamente na pedra. Já não se mexe. $A$ lagartixa acabou morrendo"

- "eu" presencia in loco a passagem da vida para a morte, e é tam. bém o causador direto dessa passagem. E o círculo da vida e da morte iniciado com a abelha (morte consumada), continuado com o rato (vida $\rightarrow$ morte) e terminado com a lagartixa (morte presenciada).

Nas duas primeiras ligaçốes (eu-abelha/eu-rato), temos um "eu" que faz uma reflexão através desses dois seres, e na ligação eu-lagarti$x a$, já existe uma espécie de fusão entre o "eu" e a lagartixa, na medida em que temos:

"Senti como se restássemos só eu e a lagartixa, e senti isso colocando-me no lugar dela"

Através dessa identidade, chega-se à conclusấo de que entre o viver $\mathrm{e}$ o morrer não existe tanta diferença, sendo que é somente através da interação de ambos que se forma um todo, o círculo vida-morte.

O que nos resta observar é a posição do "eu" perante a morte. Podemos notar, pelos trechos citados, que o que existe com relaçăo à morte não é propriamente o medo dela, mas sim o medo de não poder esboçar qualquer reação diante dela. $O$ personagem se encontra completamente desarmado e indefeso para enfrentá-la. A conscientização dessa incapacidade de poder controlar a vida ou a morte, significa para o "eu", a conscientização da sua não-onipotência, o que vai ferir aquilo que há de mais essencial para o "eu": o seu ego. $E$ tudo aquilo que foge ao controle do ego torna-se incerto, o "eu" fica sem ter onde se firmar. Daí, um "eu" quase passivo, como alguém que se entrega a uma tropa inimiga, depois de derrotado numa ferrenha luta.

"O viver e o morrer, esses dois fatos, não são opostos. Pareceu-me não haver tanta diferença assim. Já estava relativamente escuro. A visão só captava as luzes longínquas. A sensação do pisar, também distanciando-se da visão, era extremamente incerta. Somente a cabeça funcionava livremente. Isso me impulsionava ainda mais em direção a essa atmosfera." 
Ao chegarmos aqui, a impressão que temos é de que o "eu" chega a um beco sem saida, e tudo se acaba. mas quero acreditar que não. O "eu", ultrapassando o ego ferido, parece procurar novos rumos para a sua vida. $E$, creio que o fato de o seu relato não ter terminado aqui mas, ao contrário, ter incluído as frases finais

“Depois de três semanas, eu parti dali. E depois disso, já se passaram mais de três anos. De ficar com cáries da coluna, $(8)$ eu escapei."

isso parece surgir como uma pontinha de luz ao longe, onde ainda existe a esperança. E como se ele quisesse nos dizer: "Apesar de tudo, ainda estou aqui, VIVO! E é o que importa!"

\section{NOTAS}

(1) Kinasaki nite - Em Kinosaki, obra de 1917.

(2) Nayoa Shiga - renomado escritor japonês, nascido na província de Miyagi, em 1883 e falecido em 1971. Dentre as suas principais obras incluem-se, além de Kinosaki nite: Abashiri made (Até Abashiri), 1910; Han no hanzai (O crime de Han), 1913; Anya kōro (O caminho numa noite escura), 1921. 1937; Kozo no kamisama (O deus do aprendiz), 1920, etc.

(3) O protagonista "eu" é típico de obras que no Japão se incluem no gênero chamado watakushi shōsetsu ou shishósetsu, tipo de romance autobiográfico. Kinosaki nite, tem forte influência desse gênero, mesmo porque Naoya Shiga é um dos grandes representantes desse gênero literário.

(4) Kinosaki - refere-se à estação termal localizada na cidade de mesmo nome na província de Hyogo, e muito famosa na regiåo oeste do Japão.

(5) Bunshō Dokuhon - obra do autor Junichiro Tanizaki, onde ele estuda a língua japonesa sobre vários aspectos.

(6) No Japão, a maioria dos rios que atravessam a cidade possuem as margens reforçadas por pedras, formando uma espécie de muro.

(7) Aoyama - refere-se ao cemitério de Aoyama, localizado no bairro de mesmo nome. Naoya Shiga e a sua fam flia eståo enterrados nesse cemitério.

(8) Cáries da coluna - uma espécie de inflamaçáo das vértebras. 